Florian Sedlmeier*

\title{
Greatness and the Convertibility of Literary Capital: W. D. Howells and Black Writers
}

https://doi.org/10.1515/zaa-2020-2030

Abstract: Opening with James Weldon Johnson's discourse on artistic greatness, I discuss William Dean Howells's assessment of Paul Laurence Dunbar and Charles W. Chesnutt through the lens of the convertibility of literary capital, developed with Pierre Bourdieu. From within the racial taxonomy and with white middle-class readers as implied addressees, Howells conceives of both writers as participating in a literary market, a field structured by the tenets of realism. Howells endows Dunbar with universal literary capital and creates a regional affiliation that breaches the color line, before he singles out his poems written in vernacular notation as lasting contributions and asserts the valence of such notation as general poetic practice. On Chesnutt he bestows literary capital by marking and converting two innovations: the genre of the short story and the representation of a world in-between the racial divide. In turn, the convertibility of that world is secured by a comparison of social class habits.

\section{Realism and the Convertibility of Literary Capital}

In the preface to the first edition of his anthology The Negro Book of American Poetry James Weldon Johnson claims: "The final measure of the greatness of all peoples is the amount and standard of the literature and art they have produced" (Johnson 1922, p. 9). At the dawn of the Harlem Renaissance, Johnson draws on the link between the greatness of a distinct demographic and the greatness of its bohemian talents, stressing the need for both quantity of output and literary "standard." Arguing from within genteel parameters that his generation of writers has received qua education (cf. Müller 2013; cf. Tomsich 1971), he goes on to make the case for folk tales, songs of protest, theatrical performance, and jazz as

*Corresponding author: Prof. Dr. Florian SedImeier, John F. Kennedy Institute for North American Studies, Freie Universität Berlin, Lansstr. 7-9, 14195 Berlin, Germany,

E-mail: florian.sedlmeier@fu-berlin.de

Ә Open Access. @ 2020 Florian Sedlmeier, published by De Gruyter. (c) BY under the Creative Commons Attribution 4.0 International License. 
distinctive contributions of Black Americans to the national arts. What is more, these modes of cultural expression carry "the power of creating that which has universal appeal and influence” (Johnson 1922, p. 10). In Johnson's retroactive legitimation, they have come to define universal artistic greatness. Against charges of racial inferiority, they grew into a 'standard' and were thus converted into markers of national-cultural distinction. Some pages later, his inquiry turns to the question of racial authorial identity: "Is it not curious to know that the greatest poet of Russia is Alexander Pushkin, a man of African descent; that the greatest romancer of France is Alexandre Dumas, a man of African descent [...]?” (Johnson 1922, p. 21). In elevating parallelisms, he effectively relocates European literary greatness, which is informed by both national identity and genre affiliation, genealogically in "African descent." While these "curious" rhetorical questions expose European literary history as inextricable from colonialism, they also signal a more advanced canonization, a higher degree of literary prestige, and greater economic success of these nineteenth-century writers of "African descent," who belong to Europe's nobility.

Notably, the transnational references to Dumas and Pushkin are reverberations from William Dean Howells's introduction to Paul Laurence Dunbar's The Lyrics of Lowly Life (1896). Here Howells looks back at his own earlier review of Dunbar's Majors and Minors: Poems (1896), published in his column "Life and Letters" (1896) for Harper's Weekly. He asserts that he initially thought he had witnessed "the first instance of an American negro who had evinced innate distinction in literature" (Howells 1950, p. viii). "In my criticism of his book," he continues his self-reflection, "I had alleged Dumas in France; and I had forgetfully failed to allege the far greater Pushkin in Russia” (Howells 1950, p. viii). Turning to the discourse of racial authorial identity, he adds that "these were mulattoes, who might have been supposed to derive their qualities from white blood vastly more artistic than ours" (Howells 1950, p. viii). As such, they "were the creatures of an environment more favorable to their literary development" (Howells 1950, p. viii). Both European "white blood" and national-cultural substrate make them artistically superior, nourish their literary progress. Implied we find an authorial one-drop rule of sorts, according to which the whiter a writer is, the more likely he can achieve literary greatness. Decisively, however, Howells cites this twofold supposition as such ("might have been supposed") and does not outright endorse it.

Johnson mobilizes the discourse of mixed-race authorial identity, which complements the emergence of stories and novels of racial miscegenation in the 1890s, to demonstrate that the greatness of European and American literatures is inextricable from colonial subjugation and cultural contact. Howells references the same racial taxonomy, substantiated with a rhetoric of blood, according to which literary greatness needs whiteness and education. In his rendition of the 
discourse, though, Dunbar rather serves to prove the contrary. Dunbar himself, it is widely documented, felt pigeonholed by Howells (cf. Andrews 1993; Jarrett 2007). He read the Dean's literary endorsement as a prompt to focus on writing poetry in racialized vernacular notation; he read it, by extension, as a relegation to the confines of low, popular culture. Against this backdrop, Johnson's recontextualized paraphrases deny the institutional gatekeeper Howells, effectively claiming that the arts breach the one-drop rule that defines the color line.

Methodologically, one can read Johnson's and Howells's discourse of literary achievement and greatness in the terms provided by Pierre Bourdieu, and one can partly reread Bourdieu's terminology through their discourse. For nineteenth-century France, Bourdieu argues that the modern literary field strives for autonomy. Developing the notion of an art for art's sake, agents assert literature's "independence with respect to external powers, political or economic” (Bourdieu 1996, p. 61). While authors ever since Romanticism are acutely aware of the forces of the market and address them in their texts (cf. Gilmore 1985 for the US context), the claim to the autonomy of the artistic field creates an inverse relation to these forces, manifest in a separate, distinctly literary market. In order to read the specific valences of the literary trade, Bourdieu retains the conceptual metaphor of capital, central to Marxist thinking, for exploring the dynamics of "the market for symbolic goods" (Bourdieu 1996, p. 141), which constitutes the field. Literary capital is a specific kind of currency, which expresses social distinction and cultural prestige.

In the US, the differentiation between aesthetic autonomy and the economic market, between high art and popular culture, cannot be maintained to the same degree (cf. Levine 1988). As Günter Leypoldt notes, several "of the best-known nineteenth-century authors were able to combine commercial success with peerbased literary prestige" (Leypoldt 2013, p. 16). At the same time, due to the imagination of the US as a nation of immigrants and as structured by the color line, literary capital can be thought in more flexible terms that allow for the gradual accommodation of social differences informed by racial identity. At stake, then, is what I call, with a nod to Bourdieu's use of economic vocabulary, the convertibility of such differences into literary capital that in turn carries residuals of genteel standards and positions of social class, which most critics of the late nineteenth century cite in their rhetoric. Such convertibility is possible, not least because "the relative autonomy of the field" (Bourdieu 1996, p. 248) unfolds in a progressive dynamic, because its "history [...] is truly irreversible" (Bourdieu 1996, p. 242). Every newly created position has to reference this history; it is affected by potential changes of the social field; and it is conditioned by possibilities of publication and protocols of reception. 
In the 1880s and 1890s, the peak moment of realism, literary, political, and social concerns are discussed in the magazine market, which grows with unprecedented rapidity (cf. Johanningsmeier 1997, p. 15). Producing literature as an institution, it generates publications as diverse as the Colored American Magazine and the Ladies Home Journal. In spite of a variety of agendas and from within this market, literary standards center on what Nancy Glazener calls " "the Atlantic group”" (Glazener 1997, p. 5; original emphasis) - a set of high-brow magazines that bolster realism's rise to discursive prominence. Building on Bourdieu, she holds that realism cannot do without mechanisms of elite distinction, generating "the institution of high realism," which is consolidated by "the belletristic branch of the publishing industry" and "Boston's bourgeoisie” (Glazener 1997, p. 24), and which advances a universal standard of literary capital.

This is one way of reading literary capital in its relation to social demographics. There is a complementary one, though. Since realism, which draws on "the tradition of 'social art"” (Bourdieu 1996, p. 71), cannot be separated from the color line either, since "the critical concerns of realists intersected [...] with the politics of race” (Warren 1993, p. 11), authorial positions, aesthetic affiliations, and reader expectations are racialized. Such racial markings are, with Bourdieu, acts of “"symbolic violence”" (Buschendorf and Franke 2014, p. 78) that may, in turn, open the possibility of positioning the resulting social differences as distinctive. At times, racial marking reinforces tenets of scientific racism, as Cathy Boeckmann argues in her study of character discourse (Boeckmann 2000). At other times, it prepares a proto-pluralist conception of literary history, artistic expression, and authorship that anticipates the sociological model of Horace Kallen's cultural pluralism and prefigures an ethnographic concept of culture informed by "groupbased difference” in the name of a "cultural realism”" (Elliott 2002, p. xviii). Drawing on Bourdieu's concepts of taste and distinction, Phillip Barrish accommodates this development and argues that realism in the wake of Howells aims to produce "cultivated readers of dialect" (Barrish 2001, p. 16; original emphasis) among the white middle-class. Expressed in notations of vernacular idioms and other modes of representation, social differences can be converted into literary capital. In the specific context of late nineteenth-century North America, the convertibility resulting from the confrontation of the literary with racialized difference in particular informs what Bourdieu in the subtitle to The Rules of Art calls the "genesis and structure of the literary field" (Bourdieu 1996, n. pag.).

In my essay I trace Howells's conversions of literary capital in the cases of Dunbar and Charles Waddell Chesnutt. Against the racist prejudice that Black Americans are incapable of producing poetry, Howells assigns Dunbar the capacity to accrue universal literary capital. Framing him as a fellow Midwesterner, he creates a story of racial uplift that allows him to position Dunbar's poems 
written in vernacular diction and notation, which he regards as a sociolinguistic habit turned poetic practice and converted into distinctive literary capital, as the contribution to the literary field. The case of Chesnutt is different, not least because his mixed-race identity exposes the cruel absurdity of the laws of segregation. Howells ascribes Chesnutt's writings a twofold literary innovation from within realism. First, in terms of their investment in the genre of the short story, and second, in terms of their topical content: the representation of racial miscegenation, which he converts into tales of class distinction that facilitate comparisons of social habits across the demographics separated by the color line. Assigning them literary greatness, he marks both writers racially, but he also leaves open the possibility that they refuse to be racial representatives.

\section{Howells and Dunbar: Literary Greatness and Racial Difference}

Gene Andrew Jarrett argues that Howells judges Dunbar's writing by "the protocols of minstrel realism: the humor and dialect of black culture" (Jarrett 2007, p. 33). Realism's claim to an aesthetic of "racial authenticity" (Jarrett 2007, p. 32) cannot but reproduce a romanticized fantasy that is defined by its entertainment value and a high degree of economic marketability. The result is a "racial realism of minstrelsy" (Jarrett 2007, p. 36) saturated with caricature and stereotyping. Jarrett's assessment may establish discursive security in historical hindsight. But it also misses the rhetorical complexities that can be unlocked in Howells's review turned preface, when approached through the lens of the convertibility of literary capital. Rather than fixed authorial placement and stable aesthetic judgment, a less assertive, less patronizing, and less pejorative negotiation that accentuates the fragility of both the color line and literary capital can be retrieved. Howells's preface to Dunbar's Lyrics of Lowly Life oscillates between universal and racialized literary capital, at times folding them into one another, steadily assuming its most likely historical readers: white, educated, middle-class with their expectations and prejudices.

Catering to this readership, Howells first establishes the capacity of Dunbar's poetry to cite the diction that assigns traditional poetic language universal literary valence, before he introduces the possibility of converting the notation he associates with the expression of a racialized demographic group into distinctive literary capital. His discussion shifts between claims to a literary segregation, which marks racial difference as sociolinguistic habit and thus converts it into literary capital, and to a literary desegregation, which recognizes the capacity of Dunbar's 
poetry to achieve poetic valence independent of such convertibility. He opens his preface by noting that he "should scarcely trouble the reader with a special appeal in behalf of this book," were this appeal solely tied to "the author's race, origin, and condition" (Howells 1950, p. vii). The separation of critical literary interest and racial authorial identity continues as Howells admits that Dunbar's descent from slave peoples and his work in the service industry as "an elevator-boy" are biographical "facts" which "would certainly attract me to him as a man, if I knew him to have literary ambition” (Howells 1950, p. vii). Howells's homosocial attraction to Dunbar, the worker turned poet, is contingent upon artistic aspiration. Once such aspiration generates "literary art," the critic "must judge it irrespective of these [biographical] facts” (Howells 1950, p. vii). Howells builds his critical ethos on a biographically decontextualized, and in this sense autonomous, notion of literature as "what it was in itself" (Howells 1950, p. vii).

While the first paragraph assures readers that Dunbar produces "literary art" proper, the second probes the conditions of converting representations of racial difference into literary capital. Noting that to judge him by his literary merits remains a vital task, Howells informs his readers "that the father and mother of the first poet of his race in our language were negroes without admixture of white blood" (Howells 1950, p. vii). Here the cited rhetoric of blood and the discourse of racial purity are at the service of amplifying Dunbar's literary achievement against the prejudice that Black Americans cannot produce high art, which the case of Phillis Wheatley had publicly exposed. What follows is a hagiographic report authenticated by reference to a personal conversation between Howells and Dunbar: "He has told me [...]" that his "father escaped from slavery in Kentucky to freedom in Canada" and that his "mother was freed by the events of the civil war, and came North to Ohio" (Howells 1950, p. vii), where she gave birth to her son. The mentioning of the Midwestern background and the frequent relocations, including the father's flight to freedom in Canada, destabilize the color line by implicitly relating Dunbar's biographical disposition to Howells's, who was born the son of a printer in Ohio. Drawing on the discourse of regionalism, Howells presents Dunbar, and by implication himself, as prototypically American upstarts and writers from the metaphorical heartland. In this context, Dunbar's early career indeed took shape. Before he moved to New York, he had "won regional literary fame in the early 1890s not for writing 'black,' but as a poet writing in Western dialects" (Scott-Childress 2011, p. 175). The Midwest, by implication, also emerges as a culturally inclusive and transgressive antidote to the segregated South.

Howells proceeds to mention the precarious economic circumstances of Dunbar's childhood and youth, noting that he "grew up with such chances and mischances for mental training as everywhere befall the children of the poor," that his father "had taught himself to read [and] loved chiefly to read history," that 
Dunbar's "mother shared his passion for literature, with a special love of poetry" (Howells 1950, p. vii). With history and poetry intertwined, this gendered story of self-educational family support against all economic odds is one factor in Howells's aspirational tale. Literary patronage is another. Dunbar "has never been without the warmest and kindest friends" who write "letters in cordial appreciation of the critical recognition” (Howells 1950, p. viii), which eventually prompts Howells to promote Dunbar beyond the confines of the Midwest. At the same time, he assures readers of the urban bourgeoisie that, "at home," Dunbar "was esteemed for the things he had done rather than because as the son of negro slaves he had done them" (Howells 1950, p. viii). Textual manifestations of institutional gatekeeping and patronage, these letters of recommendation confirm Dunbar's literary accomplishments regardless of racial identity, to the point that Midwesterners can assess such achievements earlier and better than the New England establishment, with which Howells is affiliated but to which he, the social upstart, also maintains critical distance.

In the preface, these and other elements, like the quotes about Dumas and Pushkin cited above, still refer to Howells's own earlier review of Majors and Minors. ${ }^{1}$ He notes that Dunbar's poetry advances "the imaginative prophecy that the hostilities and prejudices [...] were destined to vanish in the arts" (Howells 1950, p. ix). His artistic achievement is "final proof that God had made of one blood all nations of men” (Howells 1950, p. ix). For Howells, Dunbar's literary mastery not only invalidates racist bigotry. Literature here is also endowed with the potential for a universalism that erodes the "hostilities and prejudices" of a segregated society.

How does Howells, in retrospect, see himself as having arrived at such universalism? "I held that if his black poems had been written by a white man, I should not have found them less admirable" (Howells 1950, p. ix). He reasons further that he had received Dunbar's "black poems [...] as an evidence of the essential unity of the human race, which does not think or feel black in one and white in another, but humanly in all" (Howells 1950, p. ix). We should recall that the status of AfricanAmericans as humans was still undermined by the scientific debate around polygeny and monogeny as well as threatened by the white supremacist

1 It should be admitted that Howells, in his review, takes the liberty of classifying Dunbar's poems written in vernacular notation as minor and those written in standard English as major. As David Bradley and Shelley Fisher Fishkin remind us, though, the volume Majors and Minors has two sections: "Majors and Minors," which groups poems written in standard English, and "Humor and Dialect," which assembles poetry written in vernacular notation (cf. Fisher Fishkin and Bradley 2005, p. 15-6). Whatever Howells's initial motivations may have been, in his preface to Lyrics of Lowly Life, he no longer projects such evaluation, which many scholars nonetheless have cited and reiterated. 
implementation of racial segregation. Against this backdrop, the claim to a shared humanity across the color line is afforded by realist poetic experience. And the hypothetical that the "black poems" could have been written by "a white man" legitimizes poetry written in vernacular diction. It thus allows for the conversion into something more general that gains the status of a linguistic habit and poetic practice available across the color line.

It is only by building on universal literary capital that the preface to Lyrics of Lowly Life now shifts to the notion of a racial poetics: "Yet it appeared to me then, and it appears to me now, that there is a precious difference of temperament between the races which it would be a great pity ever to lose [...]" (Howells 1950, p. ix). This renewed return to a "precious difference of temperament" is presented as a looming insight on Howells's part. Dunbar, according to Howells, "studies the moods and traits of his race in its own accent of our English" (Howells 1950, p. ix). As protoethnographic studies of "moods and traits," his poems, in Howells's reading, map racial identity onto social habits, which express themselves most forcefully in vernacular poetic diction. Each poetic representation of linguistic habit adds to the "accent of our English"-a phrasing that makes Dunbar integral to "our English."

Howells labels these poems "dialect pieces," but he discards the label in the same sentence, re-describing them as "delightful personal attempts and failures for the written and spoken language" (Howells 1950, p. ix). Thus, while he classifies them as "black poems" (Howells 1950, p. ix), he also describes them as texts testing the general relation between "written and spoken language." On these grounds, he validates them as "refined and delicate art" (Howells 1950, p. ix), citing the genteel rhetoric of cultivation. In another turn, Howells detects "a finely ironical perception of the negro's limitations" and claims that "it was this humorous quality which Mr. Dunbar had added to our literature” (Howells 1950, p. ix $-\mathrm{x}$ ). While such phrasings may support Jarrett's case for a minstrel realism, the humor stressed is also one of ironic distance, a mode of reflexive critique inherent to the "'realist disposition"” (Barrish 2001, p. 5). If Howells identifies representations of vernacular humor as the key modality for placing Dunbar in the literary field, he also makes clear that his own editorial intervention is limited to authoring the preface. Leaving intact a sense of individual author positioning, he emphasizes that "the contents of this book are wholly of [Dunbar's] own choosing" (Howells 1950, p. x). These “contents" are "distinctively” Dunbar's "contribution to the body of American poetry" and "they are divinations and reports of what passes in the hearts and minds of a lowly people" (Howells 1950, p. x). He conceives the poems simultaneously as empirical accounts and prophetic visions of the emotions and intellect of a racialized group with a low social status. The ascribed characteristics constitute their artistic distinction and lasting contribution to literary history. These features determine the innovative novelty of the poems in a national literary 
field: "for the first time, in our tongue" ("tongue" here designates an inclusive poetic American English), Dunbar's vernacular poems provide a "literary interpretation of a very artistic completeness," to the effect that Dunbar "in more than one piece [...] has produced a work of art" (Howells 1950, p. x). In a prefiguration of Johnson's discourse, literary greatness and racialized difference are not mutually exclusive.

\section{Howells and Chesnutt: Genre and the Habits of the "Middle World"}

Howells, then, returns time and again to the sides of the color line from within notions of universal literary capital and artistic greatness. His assessment of Charles Chesnutt poses the discursive problem of a writer who is classifiable as neither white nor black yet both. In a review essay published with the high-brow Atlantic Monthly in May 1900, Howells examines Chesnutt's texts as a remarkable literary event, referencing “The Wife of His Youth" (1898) in particular, which had been published with the prestigious magazine. He stresses "the novelty of the material for the writer dealt not only with people who were not white, but with people who were not black enough to contrast grotesquely with white people" (Howells 1993, p. 232). Marking the stark contrast of black and white as a bizarre social fantasy (not Blackness is marked as grotesque, but the color binary is), he renders Chesnutt's characters of racial passing both novel and close "to the ordinary American in race and color” (Howells 1993, p. 232). These literary characters leave "everyone but the connoisseur in doubt whether they are Anglo-Saxon or Anglo-African” (Howells 1993, p. 232). The "ordinary,” a crucial category for Howells's rhetoric of realist criticism, here correlates with hybridity to the point that a secure difference between the races is destabilized, except for "the connoisseur" who identifies and aestheticizes such difference by converting it into cultural distinction.

A little later Howells moves from the level of literary characters to Chesnutt's ascribed racial identity, drawing on tenets of scientific racism that index a taxonomic correspondence between the fiction of blood composition and skin color: "Now, however, it is known that the author of this story is of negro blood"; this "blood," though, is "diluted [...] in such measure that if he did not admit this descent few would imagine it"; yet this composition places him in "that middle world which lies next, though wholly outside, our own" (Howells 1993, p. 232). In this extra-literary discussion, the white "we" returns, to the effect that the "middle world" is separated from the "we" of Howells's readers. And yet there remains the 
unsettling quality of the connection between visual appearance and racial identity (cf. Wiegman 1995).

What follows is a discussion of Chesnutt's literary accomplishments that affiliates race with considerations of genre. Chesnutt's "volumes of fiction are remarkable above many, above most short stories by people entirely white" (Howells 1993, p. 232-33; original emphasis). His texts "would be worthy of unusual notice if they were not the work of a man not entirely white" (Howells 1993, p. 233). Howells's rhetoric asserts that Chesnutt's texts are in fact more notable than most texts written by his "entirely white" contemporaries, in order to pose, by double negation, the hypothetical that they can be assigned literary valence regardless of the racial identity of their author. At the same time, Howells prepares his assessment that Chesnutt's writings should be appreciated apart "from their racial interest," although that interest "must have a very great and very just claim upon the critic" who classifies (Howells 1993, p. 233). He places him in a row with Ivan Turgenev, Henry James, Sarah Orne Jewett, and Mary Wilkins Freeman, effectively including him in "the good school, the only school" (Howells 1993, p. 233): literary realism which, unlike segregated schools and universities, everyone can attend.

Decisively, Howells equips his readers with divergent receptive protocols: "Yet these stories, after all, are Mr. Chesnutt's most important work," regardless of "whether we consider them merely as realistic fiction, apart from their author, or as studies of that middle world of which he is naturally and voluntarily a citizen" (Howells 1993, p. 233-34). First, his stories are positioned as Chesnutt's major contribution to the literary field, or the market of symbolic goods. They derive their literary capital from the link between "realistic fiction" and the genre of short fiction. Second, as "studies of that middle world" they can be read as manifestations of the hybrid in-between position the author occupies in the field, with political ramifications. Chesnutt is marked as "a citizen" of this world, the inhabitation of which is his inalienable right. His stories, in turn, allow white bourgeois readers to familiarize themselves "with those regions where the paler shades dwell as hopelessly, with relation to ourselves, as the blackest negro" (Howells 1993, p. 234). Shared hopelessness unites all "shades" of Black Americans and defines their relation to white bourgeois readers. The sociality of the "middle world," though, rests on a conversion into parameters of social class. It is structured by "the same social ambitions and prejudices" readers find in Anglo American society: Chesnutt "has not shown the dwellers there as very different from ourselves" (Howells 1993, p. 234). The persistence of social class hierarchies facilitates comparisons across racialized communities, in a structural parallel to the regionalized upstart narrative in the case of Dunbar. 
Howells concludes that whether Chesnutt "may be willing to own his color" or not remains "his personal affair" (Howells 1993, p. 234). Shifting back from racialized to literary specimen, he declares that the "more universal interest" in Chesnutt should be with respect to "the more than promise he has given in the department of literature” (Howells 1993, p. 234). In this institutionalized department, "there is, happily, no color line" (Howells 1993, p. 234). While he may ultimately place Dunbar as a racial representative in the literary field (after the legitimizing efforts that draw on the genteel tradition), for Chesnutt he distills a "more universal" notion of literature defined by relative aesthetic autonomy. Against the backdrop of the symbolic and real violence resulting from segregation, such affirmation of Chesnutt's literary valence also shows how Howells, not unlike Johnson, imagines the literary field as a blueprint for racial and social uplift. Chesnutt's stories of the "middle world" are a new variation in a progressively evolving literary field that destabilizes the color line.

William Andrews contends that, while Dunbar "lived to resent the irrevocable harm' which he felt Howells had done him in praising and encouraging his dialect writing” (Andrews 1993, p. 235), Chesnutt "valued Howells's suggestion in the review that he adhere to Howellsian realism and write of life as he had experienced it” (Andrews 1993, p. 236). Chesnutt, that is, accepts the attachment to realism and the primacy of experience, which allows for the conversion of racialized identities into literary capital to begin with. What is more, Howells's principal "openness to nonracial material from a black author" attests to his "fundamental acceptance of the black writer's ability and right to treat both sides of the color line, not just that side on which he had been born" (Andrews 1993, p. 237). We can trace this openness of literary treatment back to Dunbar. In a passage from his review, which he did not include in the later preface, Howells asserts that "in the artistic effect" of Dunbar's writing one would find "white thinking and white feeling in a black man" (Howells 1896, p. 630), another breach of the color line while maintaining its rhetoric. Due to his representations of the "middle world" in the innovative genre of the short story, which in tandem function as literary capital, Chesnutt does not demand such legitimation, precisely because he cannot be safely placed on either side of the racial divide. Here the openness derives from a conversion of racial difference into habits of social class distinction, which he finds in Chesnutt's "The Wife of His Youth" and which inform his middle-class notion of human sociality.

Howells's liberal openness has its limitations. In his writings on Dunbar, Chesnutt, Frederick Douglass, and Booker T. Washington, Howells sketches "a kind of psychological profile of the developing black consciousness in America" (Andrews 1993, p. 238) that follows a "campaign of reconciliation and accommodation” (Andrews 1993, p. 240). Chesnutt's more forceful The Marrow of Tradition (1901), “a portent of a new or perhaps hitherto unrecognized militancy among Afro- 
Americans," leaves Howells disturbed "in that day of American imperial expansion" (Andrews 1993, p. 241). Howells's assessment of Black writers, then, follows the more general reformist paradigm of realism, as identified by Amanda Claybaugh (cf. Claybaugh 2007). This, in turn, should not blind us to the radicality of Howells's literary field imagination, where he converts racialized social difference into literary capital, links identities that breach the color line to the emergence of new genres, and leaves open the possibility for African-American writers not to comply with racial compartmentalization.

\section{References}

Andrews, W. L. 1993. "W. D. Howells and Charles W. Chesnutt: Criticism and Race Fiction in the Age of Booker T. Washington." In On Howells: The Best from American Literature, edited by E. H. Cady, and L. J. Budd. Durham, NC: Duke University Press, 232-44.

Barrish, P. 2001. American Literary Realism, Critical Theory, and Intellectual Prestige, 1880-1995. Cambridge: Cambridge University Press.

Boeckmann, C. 2000. A Question of Character: Scientific Racism and the Genres of American Fiction, 1892-1912. Tuscaloosa, AL: The University of Alabama Press.

Bourdieu, P. 1996. The Rules of Art: Genesis and Structure of the Literary Field. Trans. S. Emanuel. Cambridge: Polity Press.

Buschendorf, C., and A. Franke. 2014. "The Implied Sociology and Politics of Literary Texts: Using the Tools of Relational Sociology in American Studies." In American Studies Today: New Research Agendas, edited by W. Fluck, E. Redling, S. Sielke, and H. Zapf. Heidelberg: Winter, 75-104.

Claybaugh, A. 2007. The Novel of Purpose: Literature and Social Reform in the Anglo-American World. Ithaca, NY: Cornell University Press.

Elliott, M. A. 2002. The Culture Concept: Writing and Difference in the Age of Realism. Minneapolis, MN: University of Minnesota Press.

Fisher Fishkin, S., and D. Bradley. 2005. "Introduction." In The Sport of Gods and Other Essential Writings, edited by S. Fisher Fishkin, and D. Bradley. New York, NY: The Modern Library, 3-22.

Gilmore, M. T. 1985. American Romanticism and the Marketplace. Chicago, IL: The University of Chicago Press.

Glazener, N. 1997. Reading for Realism: The History of a U.S. Literary Institution, 1850-1910. Durham, NC: Duke University Press.

Howells, W. D. 1896. "Life and Letters.” Harper's Weekly, June 27, 630.

Howells, W. D. 1950[1896]. “Introduction to Lyrics of Lowly Life.” In The Complete Poems of Paul Laurence Dunbar. New York, NY: Dodd, Mead \& Co, vii-x.

Howells, W. D. 1993[1900]. “Mr. Charles W. Chesnutt's Stories.” In Selected Literary Criticism, Vol. III: 1898-1920, edited by D. J. Nordloh. Bloomington, IN: Indiana University Press, 232-4.

Jarrett, G. A. 2007. Deans and Truants: Race and Realism in African American Literature. Philadelphia, PA: University of Pennsylvania Press.

Johanningsmeier, C. 1997. Fiction and the American Literary Marketplace: The Role of Newspaper Syndicates, 1850-1900. Cambridge: Cambridge University Press. 
Johnson, J. W. 1922. "Preface to the First Edition." In The Negro Book of American Poetry, edited by J. W. Johnson. New York, NY: Harcourt, Brace and Company, 9-48.

Levine, L. W. 1988. Highbrow/Lowbrow: The Emergence of Cultural Hierarchy. Cambridge, MA: Harvard University Press.

Leypoldt, G. 2013. “Introduction: Intellectual Authority and Literary Culture." In Intellectual Authority and Literary Culture in the US, 1790-1900, edited by G. Leypoldt. Heidelberg: Winter, 1-25.

Müller, T. 2013. “James Weldon Johnson and the Genteel Tradition.” Arizona Quarterly 69 (2): 85-102.

Scott-Childress, R. J. 2011. “Paul Laurence Dunbar, New Yorker.” New York History 92 (3): 167-208. Tomsich, J. 1971. A Genteel Endeavour: American Culture and Politics in the Gilded Age. Stanford, CA: Stanford University Press.

Warren, K. 1993. Black and White Strangers: Race and American Literary Realism. Chicago, IL: The University of Chicago Press.

Wiegman, R. 1995. American Anatomies: Theorizing Race and Gender. Durham, NC: Duke University Press. 